\title{
Pinnatoxin G is responsible for atypical toxicity in mussels (Mytilus galloprovincialis) and clams (Venerupis decussata) from Ingril, a French Mediterranean lagoon
}

\begin{abstract}
Philipp Hess ${ }^{\mathrm{a}, *}$, Eric Abadie ${ }^{\mathrm{b}}$, Fabienne Hervé ${ }^{\mathrm{a}}$, Tom Berteaux ${ }^{\mathrm{b}}$, Véronique Séchet ${ }^{\mathrm{a}}$, Romulo Aráoz ${ }^{\mathrm{c}}$, Jordi Molgóc, Armen Zakarian ${ }^{\mathrm{d}}$, Manoëlla Sibat ${ }^{\mathrm{a}}$, Thomas Rundberget ${ }^{\mathrm{e}}$, Christopher O. Miles $^{\mathrm{e}}$,
\end{abstract} Zouher Amzil ${ }^{a}$

\footnotetext{
a Ifremer, Laboratoire Phycotoxines, Centre Atlantique, 44311 Nantes Cedex, France

${ }^{\mathrm{b}}$ Ifremer, Laboratoire Environnement Resources - Languedoc Roussillon, 34203 Sète, France

${ }^{\text {c }}$ CNRS, Laboratoire Neurobiologie et Développement, UPR 3294, 91198 Gif-sur-Yvette, France

d Department of Chemistry and Biochemistry, University of California, Santa Barbara, CA 93106-9510, United States

${ }^{\mathrm{e}}$ Norwegian Veterinary Institute, P. O. Box 750 Sentrum, 0106 Oslo, Norway
}

*: Corresponding author : Philipp Hess, email address : philipp.hess@ifremer.fr

\begin{abstract}
:
Following a review of official control data on shellfish in France, Ingril Lagoon had been identified as a site where positive mouse bioassays for lipophilic toxins had been repeatedly observed. These unexplained mouse bioassays, also called atypical toxicity, coincided with an absence of regulated toxins and rapid death times in mice observed in the assay.
\end{abstract}

The present study describes pinnatoxin $G$ as the main compound responsible for the toxicity observed using the mouse bioassay for lipophilic toxins. Using a well-characterised standard for pinnatoxin $G$, LC-MS/MS analysis of mussel samples collected from 2009 to 2012 revealed regular occurrences of pinnatoxin $G$ at levels sufficient to account for the toxicity in the mouse bioassays. Baseline levels of pinnatoxin $\mathrm{G}$ from May to October usually exceeded $40 \mathrm{\mu g} \mathrm{kg}^{-1}$ in whole flesh, with a maximum in September 2010 of around $1200 \mathrm{ug} \mathrm{kg}^{-1}$. These concentrations were much greater than those at the other 10 sites selected for vigilance testing, where concentrations did not exceed $10 \mathrm{\mu g} \mathrm{kg}^{-1}$ in a 3month survey from April to July 2010, and where rapid mouse deaths were not typically observed. Mussels were always more contaminated than clams, confirming that mussel is a good sentinel species for pinnatoxins. Profiles in mussels and clams were similar, with the concentration of pinnatoxin $A$ less than $2 \%$ that of pinnatoxin $G$, and pteriatoxins were only present in non-quantifiable traces. Esters of pinnatoxin $G$ could not be detected by analysis of extracts before and after alkaline hydrolysis. Analysis with a receptor-binding assay showed that natural pinnatoxin $G$ was similarly active on the nicotinic acetylcholine receptor as chemically synthesized pinnatoxin G. Culture of Vulcanodinium rugosum, previously isolated from Ingril lagoon, confirmed that this alga is a pinnatoxin $\mathrm{G}$ producer $\left(4.7 \mathrm{pg} \mathrm{cell}^{-1}\right)$. Absence of this organism from the water column during prolonged periods of shellfish contamination and the dominance of non-motile life stages of $V$. rugosum both suggest that further studies will be required to fully describe the ecology of this organism and the accumulation of pinnatoxins in shellfish. 


\section{Highlights}

- HRMS confirmed Vulcanodinium rugosum (IFR-VRU-01) from France produces PnTX-G. The nAChR binding assay showed that synthetic and natural PnTX-G have similar activity. PnTX-G explains positive MBA results observed since 2006 in shellfish from Ingril. PnTX-G higher in mussels than in clams \& highest reported so far $\left(>1200 \mu \mathrm{g} \mathrm{kg}^{-1}\right)$.

Keywords: Cyclic imines ; Shellfish toxin ; Accumulation ; Liquid chromatography coupled to tandem mass spectrometry (LC-MS/MS) ; Unexplained mouse toxicity 


\section{Introduction}

Pinnatoxins (PnTXs) had initially been isolated from Pinna muricata collected in Japan (Chou et al., 1996a; Chou et al., 1996b; Takada et al., 2001a; Uemura et al., 1995), the same genus of mollusc associated in the early 1990s with a Pinna attenuata poisoning in China. Metabolism pathways were subsequently postulated by Selwood et al. (2010) to explain biotransformation of the algal metabolites PnTXs E, F and G into shellfish metabolites PnTXs A, B, C and D and pteriatoxins A, B and C, initially reported by Hao et al. (2006) and Takada et al. (2001b). The biological source of pinnatoxins had been unknown until a PnTXproducing dinoflagellate was discovered in New Zealand in 2010 (Rhodes et al., 2010). Subsequently, this organism was taxonomically identified as a previously undescribed dinoflagellate, Vulcanodinium rugosum (Nézan and Chomérat, 2011). A strain of this species was also recently isolated from Japanese (Smith et al., 2011) and from Chinese waters (Zeng et al., 2012).

In addition to the abovementioned reports on PnTXs from South East Asia, Australia and New Zealand, PnTXs have recently also been reported from Europe, specifically Norway (Miles et al., 2010; Rundberget et al., 2011), and from North America (McCarron et al., 2012). PnTXs can thus be considered to be fairly widespread. Maximum concentrations so far have been reported to be below $110 \mathrm{\mu g} \mathrm{kg}^{-1}$ whole shellfish flesh in Canada (McCarron et al., 2012), below $120 \mu \mathrm{g} \mathrm{kg}^{-1}$ in Norway (Rundberget et al., 2011) and below $200 \mu \mathrm{g} \mathrm{kg}^{-1}$ in New Zealand (McNabb et al., 2012). These low levels appear very much in line with those typically found for spirolides: a relatively extensive data set with 1801 shellfish samples from France, Italy and the Netherlands showed a $95^{\text {th }}$ percentile of $8.9 \mu^{~ ~ k g^{-1}}$ and a maximum of $105 \mathrm{\mu g} \mathrm{kg}^{-1}$ for the sum of total spirolides over the 7-year period from 2002 to 2008 (EFSA, 2010).

Pinnatoxins exhibit fast-acting toxicity when injected intraperitoneally into mice (Munday et al., 2012), like many other toxins from the cyclic imine group of compounds (EFSA, 2010; Munday, 2008). The high intrinsic toxicity of pinnatoxins is indicated by low $L D_{50} S$ i.p. in mice, namely 57, 13 and $48 \mathrm{\mu g} \mathrm{kg}^{-1}$ bodyweight for PnTXs-E, $-\mathrm{F}$ and $-\mathrm{G}$, respectively (Munday et al., 2012). In addition, the uptake from the gastro-intestinal tract has also been shown in mice, both for voluntary feeding and classical gavage exposure routes (Munday et al., 2012). These authors also report that there is only a comparatively small differential between the i.p. and the per os routes of exposure, i.e. a factor of about 3 for PnTX-G, and hence the toxic potential of PnTX may constitute a risk to consumers of contaminated shellfish.

Only one poisoning event had ever been linked to the bivalve genus Pinna (Zheng et al. (1990) cited in Selwood et al. (2010)). Even so, the putative initial poisoning event in China may well not have been caused by pinnatoxins, as the presence of this toxin group was not demonstrated in this first event, and potential contamination with pathogenic vibrio had also been reported from that area. No acute poisoning events have been reported in direct relation to contamination with PnTXs before or since their chemical characterisation in 1995. Possible confusion may arise from the fact that PnTX-G, one of the main algal metabolites, has the same chemical sum formula $\left(\mathrm{C}_{42} \mathrm{H}_{63} \mathrm{NO}_{7}\right)$ as spirolide $B$ and 13-desmethyl-spirolide $D$ (Figure 1), two other representatives from the cyclic imines group of fast acting toxins. Even though spirolides are produced by a different genus of dinoflagellate, i.e. Alexandrium ostenfeldii (Cembella et al., 1999) and Alexandrium peruvianum (Borkman et al., 2012; Touzet et al., 2008), they accumulate in shellfish and due to the absence of sufficient reference calibration standards may thus have been confounded with PnTX-G. However, no acute poisonings have been associated with this toxin group either. Unlike spirolides, PnTXs are chemically rather stable compounds: they resist alkaline hydrolysis in aqueous methanol, at $76^{\circ} \mathrm{C}$ for $40 \mathrm{~min}$ (Rundberget et al., 2011) and aqueous $\mathrm{HCl}\left(\mathrm{pH} \mathrm{1.5)}\right.$ at $40^{\circ} \mathrm{C}$ for $24 \mathrm{~h}$ 
(Jackson et al., 2012). Due to this unusual stability, and their high oral toxicity, PnTXs may be a significant threat to shellfish consumers.

Unfortunately, there is a general lack of information on occurrence for a large number of toxin groups on one hand, and epidemiological information on the other. The lack of information on toxin occurrence has been to some extent overcome by the use of the lipophilic mouse bioassay, also leading to criticism of this test, suggesting its potential for "false" positives. Several comparisons of chemical analyses using liquid chromatography coupled to mass spectrometry (LC-MS) or to tandem mass spectrometry (LC-MS/MS) with the mouse bioassay (MBA) have been conducted as part of routine shellfish safety surveillance programs, e.g. in Ireland and France (Belin et al., 2009; Clarke et al., 2006). In France, the mouse bioassay protocol for lipophilic toxins is based on the EU harmonised protocol, using a 24h observation period and dichloro-methane as solvent for the partitioning clean-up (Yanagi et al., 1989; Yasumoto et al., 1984). The French study classified unexplained MBA positives as atypical toxicity (Belin et al., 2009). In this 6-year study (2003-2008), over 1000 shellfish samples were analysed using both LC-MS/MS and MBA, with over $25 \%$ of the MBA positives being not explained by chemical analysis.

This large percentage of unexplained MBA results prompted us to investigate several monitoring sites further. Here, we report the findings concerning Ingril Lagoon, with PnTX-G identified as the main source of MBA positives observed since 2006 in this lagoon. Particular attention is given to the levels and profiles of PnTXs in mussels and clams, the two main shellfish species occurring naturally in this lagoon. PnTX-G levels in cultures of the toxinproducing organism are reported, as well as results from a functional assay based on the mode of action of the toxin on the Torpedo nicotinic acetylcholine receptor (nAChR) (Aráoz et al., 2012).

\section{Materials and methods}

\subsection{Collection of shellfish samples}

Shellfish samples were obtained from 11 sites for vigilance surveillance, i.e. parallel analysis by LC-MS/MS and the lipophilic MBA. Samples from Ingril Lagoon had been obtained during the four years from 2009 to 2012. Samples from 2009 had been obtained as digestive gland tissues, while samples from 2010 to 2012 had been whole flesh samples. For 2012, both whole flesh and digestive glands of mussel samples were obtained separately on 14 occasions. Samples from 2009 and 2010 had been stored as $\mathrm{MeOH}$-extracts prior to reanalysis in 2011, while samples from 2011 and 2012 had been analysed shortly after sampling.

\subsection{Pinnatoxin $\mathrm{G}$ standard}

PnTX-G had previously been isolated from shellfish originating from New Zealand at Cawthron Institute (Selwood et al., 2010). An aliquot of this material, but only quantified by gravimetric analysis, had been used in 2010 for the analysis of the survey samples at the Norwegian Veterinary Institute (NVI). Subsequently, in 2011, the quantity of the isolated toxin was confirmed at the NRCC (CA) using quantitative nuclear magnetic resonance (qNMR). An aliquot of this well-characterised PnTX-G was used to prepare a calibration standard in degassed methanol $(0.01 \%$ acetic acid), which has been provided to Ifremer at an approximate concentration level of $2 \mu \mathrm{g} \mathrm{mL}^{-1}$. Stability of the standard had been tested at NRCC, and no degradation was observed during a 2-week period at temperatures from -20 to $+40^{\circ} \mathrm{C}$. Dilutions of this standard in $\mathrm{MeOH}$ were used to quantify PnTXs in shellfish 
samples from Ingril Lagoon. Aliquots of this standard were also compared with synthetic PnTX-G, produced in the laboratory of A. Zakarian (Araoz et al., 2011), using a Torpedo microplate receptor-binding assay (Aráoz et al., 2012) to verify the biological activity on the nAChR target.

\subsection{LC-MS/MS analyses of pinnatoxins}

2.3.1. Analysis of French shellfish samples from the vigilance surveillance programme in 2010 (Norwegian Veterinary Institute, triple-stage quadrupole)

Mussels were collected from the vigilance sentinel sites (Figure 2), digestive glands (DGs) were dissected, and weights of both DGs and remaining flesh recorded. Subsequently, homogenised aliquots $(2 \mathrm{~g})$ of these DG tissues were extracted with methanol $(\mathrm{MeOH}, 1: 9$ $w / v)$. Filtered aliquots of these extracts were provided to the Norwegian Veterinary Institute for LC-MS/MS analysis.

Liquid chromatography was performed on an Xbridge C18 column $(3 \mu \mathrm{m}, 50 \times 2.1 \mathrm{~mm})$ (Waters, Milford, MA, USA), using a Waters Acquity UPLC module. Separation was achieved using linear gradient elution at $0.3 \mathrm{~mL} \mathrm{~min}^{-1}$ starting with acetonitrile-water (25:75, water containing $5 \mathrm{mM}$ ammonium carbonate) rising to $100 \%$ acetonitrile over $9 \mathrm{~min}$. Isocratic elution with $100 \%$ acetonitrile was maintained for 5 min before the eluent was switched back to $25 \%$ acetonitrile. The UPLC system was coupled to a Quattro Ultima Pt triple quadrupole mass spectrometer with an ESI interface (Waters Micromass, Manchester, UK). Instrumental parameters and ion transitions were the same as previously described (Rundberget et al., 2011). Quantitation was performed relative to the PnTX-G standard from Cawthron Institute and the detection limit was $0.5 \mathrm{\mu g} \mathrm{kg}^{-1}$ whole shellfish flesh.

\subsubsection{Analysis of shellfish samples from Ingril Lagoon (Ifremer, triple stage quadrupole)}

\subsubsection{Solvents and reagents}

Acetonitrile (LC-MS grade) and methanol (HPLC grade) were obtained from JT Baker. Water for analysis was supplied by a Millipore system. Ammonium formate (LC-MS quality) and formic acid (analyses quality) were from Sigma Aldrich. PnTX-G reference material (CRM) was obtained from the NRC (Halifax, Canada) and diluted in methanol to calibration levels from $0.5 \mathrm{ng} \mathrm{mL}^{-1}$ to $100 \mathrm{ng} \mathrm{mL}^{-1}$.

\subsubsection{Extraction}

At least $100 \mathrm{~g}$ of whole mussel or clam tissue (or $30 \mathrm{~g}$ of DG) was homogenized with a blender. Methanol $(9 \mathrm{~mL})$ was added to aliquots of shellfish tissue $(2 \mathrm{~g})$, and toxins were extracted using a high speed homogenizer (Polytron) at $15000 \mathrm{rpm}$ for $2 \mathrm{~min}$. Samples were then centrifuged at $3700 \mathrm{~g}$ for $8 \mathrm{~min}$ at $4^{\circ} \mathrm{C}$, and supernatants transferred to $20 \mathrm{~mL}$ volumetric flasks. This extraction was repeated twice and volumetric flasks were made up to $20 \mathrm{~mL}$ with $\mathrm{MeOH}$. Aliquots of extracts were filtered $(0.2 \mu \mathrm{m}$ membrane filters $)$ and analyzed by LC-MS/MS.

\subsubsection{LC-MS/MS}

Analysis of pinnatoxins was performed on a UFLC (model Nexera, Shimadzu) coupled to a triple-quadrupole mass spectrometer (5500Qtrap, AB Sciex). Chromatography was 
performed with a Hyperclone MOS C8 column $(50 \times 2.0 \mathrm{~mm}, 3 \mu \mathrm{m})$ with a C8 guard column $(4 \times 2.0 \mathrm{~mm}, 3 \mu \mathrm{m}$, Phenomenex). A binary mobile phase was used, phase A $(100 \%$ aqueous) and phase B (95\% aqueous acetonitrile), both containing $2 \mathrm{mM}$ ammonium formate and $50 \mathrm{mM}$ formic acid. The flow rate was $0.2 \mathrm{~mL} \mathrm{~min}^{-1}$ and injection volume was $5 \mu \mathrm{L}$. The column and sample temperatures were $25^{\circ} \mathrm{C}$ and $4^{\circ} \mathrm{C}$, respectively. A gradient elution was employed, starting with $30 \% \mathrm{~B}$, rising to $95 \% \mathrm{~B}$ over $2.5 \mathrm{~min}$, held for $5 \mathrm{~min}$, then decreased to $30 \% \mathrm{~B}$ in $0.1 \mathrm{~min}$ and held for $2.5 \mathrm{~min}$ to equilibrate the system.

The LC-MS/MS system was used in positive ionization and multiple reaction monitoring (MRM) mode, with the following three transitions per compound: PnTX-G $\mathrm{m} / \mathrm{z} 694.4 \rightarrow 676.4$, $694.4 \rightarrow 458.3$ and $694.4 \rightarrow 164.1$; PnTX-A $\mathrm{m} / \mathrm{z} \quad 712.4 \rightarrow 694.4, \quad 712.4 \rightarrow 458.3$ and $712.4 \rightarrow$ 164.1, PnTX-B and $\mathrm{C}, \mathrm{m} / \mathrm{z} 741.4 \rightarrow 723.5,741.4 \rightarrow 458.3$ and $741.4 \rightarrow 164.1$; PnTX-D, $\mathrm{m} / \mathrm{z} 782.4 \rightarrow 764.4$ 782.4 $\rightarrow 488.3$ and $782.4 \rightarrow 164.1$; PnTX-E, $\mathrm{m} / \mathrm{z}$ 784.4 $\rightarrow 764.4$ 784.4 $\rightarrow 488.3$ and $784.4 \rightarrow 164.1$; PnTX F, $\mathrm{m} / \mathrm{z}$ 766.4 $\rightarrow 738.4,766.4 \rightarrow 488.3$ and $766.4 \rightarrow 164.1$; pteriatoxins $\mathrm{A}, \mathrm{B}$ and $\mathrm{C} \mathrm{m} / \mathrm{z} 831.5 \rightarrow 787.5,831.5 \rightarrow 458.3$ and $831.5 \rightarrow 164.1$. The most intense transition, giving the product ion $\mathrm{m} / \mathrm{z} 164.1$, was used to quantify toxins. All toxins were quantified against the PnTX-G standard from NRC, assuming that all analogues (pinnatoxins and pteriatoxins) had the same response factor as PnTX-G.

The ESI interface was operated using the following parameters: curtain gas $30 \mathrm{psi}$, temperature: $650^{\circ} \mathrm{C}$, gas $150 \mathrm{psi}$; gas $260 \mathrm{psi}$, ion spray voltage $5500 \mathrm{~V}$. For detection, parameters were: the declustering potential was $30 \mathrm{~V}$ and the entrance potential $10 \mathrm{~V}$. Three collision energies were applied $(53,59$ and $67 \mathrm{eV})$ with collision cell exit potentials of 10,6 and $10 \mathrm{~V}$ for transitions 1,2 and 3 of each compound, respectively.

The limit of detection (LOD) has been determined from the signal-to-noise ratio of the lowest standard injected after injection of 20 samples, using automated calculation in the Analyst 1.5.1 software of Applied Biosystems: This algorithm calculates the LOD as the sample giving a signal height 3 times the standard deviation of the noise. The LOD for PnTX-G was $0.05 \mathrm{ng} \mathrm{mL}^{-1}$ or $0.5 \mathrm{\mu g} \mathrm{kg}^{-1}$ whole flesh, i.e. for an injection of $5 \mu \mathrm{L}$ an absolute amount of $250 \mathrm{fg}$ injected on column.

\subsubsection{Confirmatory high-resolution mass spectrometry at Ifremer (Q-ToF)}

Accurate mass data were acquired on a QTOF 6540 Agilent instrument equipped with a dual ESI source coupled to an Agilent 1200 HPLC system. Separation was carried out on an Agilent Zorbax RRHD extend C18 column $(50 \times 2.1 \mathrm{~mm}, 1.8 \mu \mathrm{m})$ at $40^{\circ} \mathrm{C}$ with a flow rate at $0.5 \mathrm{~mL} \mathrm{~min}{ }^{-1}$ using a linear gradient elution from $10 \%$ B to $100 \%$ B over $5.5 \mathrm{~min}$. $100 \%$ B was held for $2 \mathrm{~min}$ before returning to $10 \% \mathrm{~B}$ at $7.5 \mathrm{~min}$. The column was then equilibrated for 2.5 min with $10 \%$ B prior to the next run. Mobile phase A was $100 \%$ water containing $50 \mathrm{mM}$ formic acid and $2 \mathrm{mM}$ ammonium formate and $B$ was $95 \%$ acetonitrile with $5 \%$ water with 50 $\mathrm{mM}$ formic acid and $2 \mathrm{mM}$ ammonium formate.

The instrument was operated in positive mode, performing full-scan analysis over $\mathrm{m} / \mathrm{z} 100$ 1700 at 1 spectrum s ${ }^{-1}$ and targeted MS/MS analysis at 5 spectra s${ }^{-1}$. Capillary voltage and fragmentor voltage were $3500 \mathrm{~V}$ and $200 \mathrm{~V}$, respectively. The temperature of the Jet Stream Technologies source was $200^{\circ} \mathrm{C}$ with drying gas at $5 \mathrm{~L} \mathrm{~min}^{-1}$ and sheath gas at $11 \mathrm{~L} \mathrm{~min}^{-1}$ at $350^{\circ} \mathrm{C}$. Three collision energies $(20,40$ and $60 \mathrm{eV})$ were applied to the precursor ions to obtain an overview of the fragmentation pathways. The instrument has typically a mass error of $1 \mathrm{ppm}$ in full scan mode and of $2 \mathrm{ppm}$ in fragmentation mode. However, for small molecules or fragments and at low abundance this error may occasionally increase to less than $5 \mathrm{ppm}$. Resolution achieved is typically 25,000 to 40,000 , depending on molecular weight. 


\subsection{Microplate receptor-binding assay for pinnatoxin $\mathbf{G}$}

Comparison of natural PnTX-G with that obtained by chemical synthesis was performed by using a microplate-receptor binding assay recently described (Aráoz et al., 2012). Briefly, flat-bottomed Maxisorp microplates were coated with $100 \mu \mathrm{L}$ per well of purified Torpedo electrocyte membrane protein $\left(13.5 \mu \mathrm{g} \mathrm{mL}^{-1}\right)$ in TBS buffer $(150 \mathrm{mM} \mathrm{NaCl}, 50 \mathrm{mM}$ Tris- $\mathrm{HCl}$, $\mathrm{pH}$ 7.4). The plate was sealed and incubated overnight at $4^{\circ} \mathrm{C}$. The membrane solution was discarded and without washing, $250 \mu \mathrm{L}$ blocking buffer (TBS, $0.5 \% \mathrm{BSA}$ ) was added to each well, and the plate incubated overnight at $4^{\circ} \mathrm{C}$. The coated microplates are ready-to-use and are stable for months when stored at $4^{\circ} \mathrm{C}$.

For the test, the microplate was emptied and, without washing, $100 \mu \mathrm{L}$ of toxin standards prepared in blocking buffer were added to each well. The plate was sealed and incubated overnight at $4^{\circ} \mathrm{C}$. Thereafter, $50 \mu \mathrm{L}$ biotin- $\alpha$-Bungarotoxin $\left(2.4 \times 10^{-7} \mathrm{M}\right)$ was added to each well. The plate was sealed and incubated for $30 \mathrm{~min}$ under constant shaking at room temperature. Then, the wells were washed trice with $250 \mu \mathrm{L}$ washing buffer (TBS, $0.1 \%$ Tween 20 ) and $100 \mu \mathrm{L}$ of streptavidin-HRP (220 ng nL${ }^{-1}$ protein) was added to each well. The plate was sealed and incubated for $30 \mathrm{~min}$ at room temperature with constant shaking. Thereafter, the wells were washed thrice with $250 \mu \mathrm{L}$ washing buffer. To detect the complex Torpedo nAChR-biotin-a-Bungarotoxin-streptavidin-HRP, $100 \mu \mathrm{L}$ of freshly prepared peroxidase substrate OPD was added to each well. After $3 \mathrm{~min}$, the enzymatic reaction was stopped with $100 \mu \mathrm{L}$ of $0.5 \mathrm{M} \mathrm{H}_{2} \mathrm{SO}_{4}$ and absorbance $(492 \mathrm{~nm})$ measured with an ELISA plate reader (GeniosPro, Tecan, Männedorf, Switzerland). Percentage inhibition was calculated from the equation: $\%$ inhibition $=100 \times[(100 \%$ signal - signal sample $) /(100 \%$ signal - $100 \%$ inhibition) (1) where: $100 \%$ signal is obtained from wells in which Torpedo membranes were incubated in the absence of toxins or extracts. Non-specific binding was measured by incubating Torpedo electrocyte membranes with $1 \mu \mathrm{M}$ a-Bungarotoxin $(100 \%$ inhibition). The concentration of inhibitor at which biotin- $\alpha$-Bungarotoxin binding is inhibited by $50 \%\left(\mathrm{IC}_{50}\right)$ was determined by nonlinear regression analysis using GraphPad Prism 5.0 software (GraphPad Software, San Diego, CA, USA). Curve fitting was performed by nonlinear regression analysis using the Hill equation.

\subsection{Culture and analysis of Vulcanodinium rugosum}

After initial observation in 2001, V. rugosum was observed again in a Lugol's-fixed sea water sample from Ingril Lagoon in July 2009 (Nézan and Chomérat, 2011). A sample of untreated sea water was obtained the following week and used to bring the organism into culture (strain IFR-VRU-01). This strain was cultured using L1 medium, prepared using filtered $(0.2 \mu \mathrm{m})$ Mediterranean sea water $(38 \mathrm{psu})$. A batch culture $(200 \mathrm{~mL})$ was prepared at $18^{\circ} \mathrm{C}$, with a photon flux density at $200 \mu \mathrm{mol} \mathrm{m} \mathrm{m}^{-2} \mathrm{~s}^{-1}$ and a photoperiod of $16 \mathrm{~h}$ of light and $8 \mathrm{~h}$ of dark. Cells were collected during stationary phase by centrifugation of $10 \mathrm{~mL}$ aliquots $(3500$ g, $20 \mathrm{~min}, 4^{\circ} \mathrm{C}$ ), with 1,750 cells $\mathrm{mL}^{-1}$. Cell pellets were extracted three times with $0.5 \mathrm{~mL}$ portions of $\mathrm{MeOH}$. After filtration $(0.2 \mu \mathrm{m})$, extracts were evaporated to dryness and taken up in a final volume of $1 \mathrm{~mL} \mathrm{MeOH}$ for LC-MS/MS analysis.

\section{Results and discussion}

\subsection{Confirmation of structural identity and receptor-binding activity}

One difficulty was the identification of PnTX-G as a toxin distinct from spirolide B and 13desmethyl spirolide D. The standard obtained from New Zealand via the NRCC played a 
major role in this undertaking. First, this standard allowed for the verification of the retention time (RT) of the analyte observed in shellfish samples from Ingril: there was no difference in RT between the PnTX-G standard isolated at Cawthron and the RT of PnTX-G in both V. rugosum culture extracts and shellfish samples from Ingril Lagoon (electronic supplementary material Figure 1). Also, base hydrolysis did not result in destruction of the compound (see section 3.3), which suggested that the compound is not a spirolide analogue but a pinnatoxin (Rundberget et al., 2011). Furthermore, the mass spectral identity of PnTX-G in samples from Ingril Lagoon and in the standard were identical: fragments from $[\mathrm{M}+\mathrm{H}]^{+} \mathrm{m} / \mathrm{z} 694.4$ were observed at $\mathrm{m} / \mathrm{z} 458.3$ and 164.1 (electronic supplementary material Figure 1). Accurate mass analysis also confirmed these fragmentation clusters at $\mathrm{m} / \mathrm{z} 458.3256$ and 164.1429 , both in the standard and in a sample of $V$. rugosum (Figure 3 ). The mass difference of the 458-fragment between the PnTX-G observed in the sample of $V$. rugosum isolated from Ingril Lagoon and that of the standard (originating from New Zealand shellfish) was $-1.5 \mathrm{ppm}$, i.e. less than the specified acceptable mass accuracy for the instrument (i.e. $2 \mathrm{ppm}$ ). While mass spectra of spirolide $B$ and 13-desmethyl spirolide $D$ also have the fragment cluster at $\mathrm{m} / \mathrm{z}$ 164.1 they do not possess the fragment at $\mathrm{m} / \mathrm{z} 458.3$ (Sleno et al., 2004). It would be extremely unlikely that two different compounds had the same accurate mass and fragmentation spectra and the same retention time. Additionally, comparison of natural PnTX-G isolated from New Zealand shellfish with chemically synthesized PnTX-G confirmed that both also had similar activity on the nicotinic acetylcholine receptor (Figure 4), strongly suggesting that if there were any potential strereochemical differences between the compounds these would not be toxicologically significant. More significantly, high resolution ${ }^{1} \mathrm{H}$ - and ${ }^{13} \mathrm{C}-\mathrm{NMR}$ spectroscopic studies with synthetic pinnatoxin $\mathrm{G}$ unambiguously confirm its structural and stereochemical identity (Aráoz et al., 2011). Taken together, these comparisons show that the compound observed in samples from Ingril Lagoon was indeed PnTX-G.

\subsection{Occurrence of pinnatoxins in shellfish from France (3-month survey)}

In 2010, retrospective analysis of shellfish extracts from the French vigilance surveillance programme was performed (Table 1). This analysis showed regular occurrence of low levels of spirolides, while only mussels from two sites contained PnTX-G (one in Brittany and one in the Mediterranean Sea (the Etang de Prévost is adjacent to Ingril Lagoon)) at very low levels. Such very low levels are quantifiable because cyclic imines generally exhibit high response factors in LC-MS/MS. However, such low levels may result from the presence of a live PnTXproducing organism with benthic life stages in those areas, but might also potentially be due to contamination arising from advected water bodies.

\subsection{Occurrence of pinnatoxins in mussels and clams from Ingril Lagoon (4-year survey)}

The presence of the low levels of PnTX-G at two locations prompted us to study other geographical areas of potential interest, based on the 6-year survey by Belin et al. (2009). One of the areas where rapid MBA deaths had been observed was Ingril Lagoon (see also electronic supplementary material Figure 2). Retrospective analysis of the routine samples from that area for 2010 showed surprisingly high levels of PnTX-G (Figure 5). These results led us to retrospectively analyse stored samples from 2009 and to survey the area for PnTXs during 2011 and 2012 (Figure 5). The 4-year survey of this area shows that PnTX-G is a recurrent toxin in both mussels and clams. Notable features of PnTX-G in this data are: i) high background concentrations; ii) high maximal concentrations; and iii) large differences in concentration between mussels and clams.

Based on the $\mathrm{LD}_{50}$ reported (Munday, 2008), an MBA $L D_{50}$ can be calculated around $40 \mu \mathrm{kg}^{-1}$ for PnTX-G in shellfish flesh. High concentrations were observed in mussels for 
prolonged periods during all four years: only on four sampling occasions was the PnTX-G concentration in mussels below $40 \mathrm{\mu g} \mathrm{kg}^{-1}$ whole flesh. Mouse bioassays performed on mussel extracts from Ingril Lagoon were positive for extended periods during the summer months in the years from 2006 to 2009. Thus, the concentrations of PnTX-G are clearly sufficient to explain the atypical toxicities observed in mice injected with extracts of mussels from Ingril Lagoon.

High maximum concentrations of PnTX-G were observed in mussels every year, i.e. 261, 1244,568 and $631 \mathrm{~g} \mathrm{~kg}^{-1}$ for 2009, 2010, 2011 and 2012, respectively. Thus, every year, the maximum concentration of PnTX-G observed in mussels at Ingril Lagoon exceeded all other reported levels worldwide, so far. The overall maximum during this study $\left(1244 \mathrm{\mu g} \mathrm{kg}^{-1}\right)$ was six-fold higher than any previously reported value. These high concentrations clearly constitute a concern that needs to be addressed in any future risk evaluation for this toxin group. As there are very few monitoring data for PnTXs (EFSA, 2010), further surveys will have to be conducted over larger geographical areas before the overall extent of contamination of shellfish with this toxin group can be assessed. It already appears from the "snapshot" analysis of the other 10 areas during the 2010 3-month survey that concentrations elsewhere in France were comparatively low. As this may also be the case in many other countries, future surveys should attempt to have a fine geographic sampling net.

Significant differences were observed between the accumulation of PnTX-G in mussels and in clams (Figure 5 and Table 2). On average, mussels contained seven- to eight-fold higher levels of PnTX-G during the same sampling occasions at Ingril Lagoon. Even though mussels in Ingril Lagoon are from natural banks in the sediment, the physiological differences between the species or the difference in ecological niche of clams, as burrowing bivalves, may play a major role in this accumulation pattern.

The hitherto described metabolic pathways leading to PnTXs A-D and pteriatoxins A-C (Selwood et al., 2010) could not be verified, but transitions consistent with pteriatoxins were found in both clams and mussels (due to the absence of calibration standards it was not possible to identify which pteriatoxins). The only quantifiable metabolite was PnTX-A but even this was only present at low percentage of the PnTX-G concentrations (Table 3 ), assuming equal response factors (as all PnTX analogues were quantified against PnTX-G). As PnTX-G is stable to alkaline hydrolysis (Rundberget et al., 2011), we used this method to determine whether esters of PnTX were present in mussel and clam samples. No differences were observed in concentration of PnTX-G before and after alkaline hydrolysis. We conclude that, if esters were present in these samples, their concentrations were negligible. This appears somewhat in contrast to findings of McCarron et al. (2012), however, multiple factors may contribute to the formation of such esters, e.g. availability of free fatty acids and species or metabolic state of shellfish.

\subsection{Tissue distribution of pinnatoxin $\mathbf{G}$ in mussels}

During 2012, it was possible to obtain simultaneously both whole flesh samples and digestive glands of mussels on 14 sampling occasions. These tissues were analysed separately to gain further insight in the tissue distribution, and thus accumulation mechanisms, of PnTXs (Table 4). The fraction accumulated in the digestive gland appeared relatively low, with only ca. $65 \%$ of total PnTX-G being accumulated in this tissue. In previous studies of other toxin groups, higher accumulation rates had been reported for digestive gland compared to whole flesh. For instance, a ratio of 5.2 for AZA concentrations in digestive gland compared to whole flesh was reported for the accumulation of AZAs in mussels, i.e. greater than $90 \%$ accumulation of AZAs in digestive gland tissue (Hess et al., 2005). Similarly, a separate study reported the ratio of OA-equivalents in digestive gland compared to whole flesh to be 6.2 and 8 in two samples of mussels (M. edulis), i.e. again $>90 \%$ accumulated in the 
digestive gland (McCarron et al., 2008). Even for domoic acid, a much more water soluble toxin, accumulation of ca. $85 \%$ in the digestive gland was reported (McCarron and Hess, 2006). The finding that a significant portion of PnTX-G is accumulated in tissues other than the digestive gland suggests that other mechanisms than direct ingestion of micro-algae might play a role in the accumulation of PnTX-G in mussels. Further studies will be necessary to ascertain whether this difference is due to greater distribution postaccumulation or whether uptake from the dissolved phase may play a role for this toxin group.

\subsection{Pinnatoxin G cell quota in Vulcanodinium rugosum, strain IFR-VRU-01}

Triplicate analysis of the batch culture of strain IFR-VRU-01 of $V$. rugosum resulted in a PnTX-G concentration of ca. $4.7 \mathrm{pg} \mathrm{cell}^{-1}$. This finding, together with the observation of the organism on several occasions in the water column of Ingril Lagoon (Nézan and Chomérat, 2011) may explain the accumulation of PnTX-G as the main toxic component identified in shellfish from this area. This concentration is similar to the previously reported values of 12 to $15 \mathrm{pg}$ cell ${ }^{-1}$ PnTX-G for a Japanese strain (Smith et al., 2011), and up to 4 and $20 \mathrm{pg}$ cell $^{-}$ ${ }^{1}$ PnTX-E and PnTX-F, respectively, for isolates from New Zealand (Rhodes et al., 2010). However, the toxin quota in cultures may vary according to culture conditions and may not be the same as that in nature, and hence further studies will be necessary to fully understand the uptake mechanisms for this organism with non-motile life stages.

\section{Conclusions}

This study has shown the production of PnTX-G in V. rugosum, strain IFR-VRU-01, isolated from Ingril Lagoon in 2009. Furthermore, the results show for the first time the presence of PnTX-G in shellfish from the French Mediterranean, in Ingril Lagoon. The levels observed in mussels from this lagoon are higher than those reported elsewhere, while the levels in clams appear similar to previously reported levels in mussels (Canada and Norway) and oysters (New Zealand). As the percentage of PnTX-G accumulated in digestive gland was lower than for most other toxin groups studied previously, a more extensive study would be required to determine the extent and the mechanisms of the contamination of bivalves destined for human consumption. Levels observed in shellfish from Ingril Lagoon were as much as two orders of magnitude higher than those observed in other areas of shellfish production in France. Even though there have not been regular reports of unexplained lipophilic mouse bioassays in other French Mediterranean lagoons, there may still be a low level of contamination with PnTXs in these areas. Thus, further studies will be necessary to establish the full extent of the problem. While the precautionary principle would suggest closure of areas with such high levels of a bioactive substance, i.e. Ingril Lagoon, a formal risk assessment may be necessary if any ill effects in humans can be demonstrated for this toxin group.

\section{Acknowledgements}

We acknowledge the collaboration of Paul McNabb and Andrew I. Selwood (both Cawthron Institute, New Zealand) and Michael A. Quilliam and Pearse McCarron (both Institute of Marine Biosciences, National Research Council Canada) for the provision of a well characterised reference solution for PnTX-G. The authors thank Thomas Glauner and Bernhard Wüst (both Agilent) for their collaboration on high resolution mass spectrometry. We also thank the technical staff of the Phycotoxin Laboratory in Nantes for help in the selection of samples and initial analysis of samples from Ingril Lagoon. 
Funding for this work came from following separate sources: i) the COLNACOQ project funded by the Regional Council of the "Pays de la Loire" (2009 - 2013); ii) the French Directorate General for Food (DGAL), through Programme 206, convention number 2011/203/2100482701 (2011 - 2012); iii) Ifremer through the ALTOX and RISCAP projects funded by the French Ministry of Research and Higher Education through programme 148 (2009 - 2012); iv) National Institutes of Health (USA, NIGMS R01 GM077379); v) the Atlantic Area Programme (Interreg IVB Trans-national): 2009-1/117 Pharmatlantic; and vi) a Marie Curie International Incoming Fellowship within the $7^{\text {th }}$ European Community Framework Programme (FP7/2007-2013) under grant agreement No. 221117 (to COM).

\section{Conflict of interest statement}

The authors declare that there is no conflict of interest for any of the authors.

\section{References}

Aráoz, R., Ramos, S., Pelissier, F., Guérineau, V., Benoit, E., Vilariño, N., Botana, L.M., Zakarian, A., Molgó, J., 2012. Coupling the Torpedo microplate-receptor binding assay with mass spectrometry to detect cyclic imine neurotoxins. Anal. Chem. 84, 1044510453.

rao , R., ervent, ., Molg , ., orga, .., r uchart-Gaillard, C., Benoit, E., Gu, Z., Stivala, C., Zakarian, A., 2011. Total synthesis of pinnatoxins A and $G$ and revision of the mode of action of pinnatoxin A. J. Am. Chem. Soc. 133, 10499-10511.

Belin, C., Soudant, D., Amzil, Z., 2009. Surveillance des toxines lipophiles dans les coquillages - Analyse statistique et comparaison des résultats obtenus par deux méthodes d'analyses: les bio-éssais sur souris et les analyses chimiques par CLSM/SM. Ifremer Archimer, 98 pages.

Borkman, D.G., Smayda, T.J., Tomas, C.R., York, R., Strangman, W., Wright, J.L.C., 2012. Toxic Alexandrium peruvianum (Balech and de Mendiola) Balech and Tangen in Narragansett Bay, Rhode Island (USA). Harmful Algae 19, 92-100.

Cembella, A.D., Lewis, N.I., Quilliam, M.A., 1999. Spirolide composition of micro-extracted pooled cells isolated from natural plankton assemblages and from cultures of the dinoflagellate Alexandrium ostenfeldii. Natural Toxins 7, 197-206.

Chou, T., Haino, T., Kuramoto, M., Uemura, D., 1996a. Isolation and structure of pinnatoxin $\mathrm{D}$, a new shellfish poison from the okinawan bivalve Pinna muricata. Tetrahedron Lett. 37, 4027-4030.

Chou, T., Kamo, O., Uemura, D., 1996b. Relative stereochemistry of pinnatoxin A, a potent shellfish poison from Pinna muricata. Tetrahedron Lett. 37, 4023-4026.

Clarke, ., evilly, L., McMahon, T., O'Cinneide, M., ilke, ., urrell, ., it gerald, O., Hess, P., Kilcoyne, J., McElhinney, M., Ronan, J., Gallardo Salas, R., Gibbons, B., Keogh, M., McCarron, M., O'Callaghan, ., Rourke, ., 2006. Review of shellfish toxicity monitoring in Ireland \& Review of management cell decisions. Proceedings of the 6th Irish Shellfish Safety Scientific Workshop Marine Institute, Galway, Pp. 22-34.

EFSA, 2010. Marine biotoxins in shellfish - Cyclic Imines (spirolides, gymnodimines, pinnatoxins and pteriatoxins), Scientific Opinion of the Panel on Contaminants in the Food chain; adopted on 5 July 2010. EFSA Journal 8, 1-39. 
Hao, J., Matsuura, F., Kishi, Y., Kita, M., Uemura, D., Asai, N., Iwashita, T., 2006. Stereochemistry of pteriatoxins A, B, and C. J. Am. Chem. Soc. 128, 7742-7743.

Hess, P., Nguyen, L., Aasen, J., Keogh, M., Kilcoyne, J., McCarron, P., Aune, T., 2005. Tissue distribution, effects of cooking and parameters affecting the extraction of azaspiracids from mussels, Mytilus edulis, prior to analysis by liquid chromatography coupled to mass spectrometry. Toxicon 46, 62-71.

Jackson, J.J., Stivala, C. ., orga, .., Molg , ., a karian, ., 2012. tability of cyclic imine toxins: interconversion of pinnatoxin amino ketone and pinnatoxin $\mathrm{A}$ in aqueous media. J. Org. Chem. 77, 10435-10440.

McCarron, P., Hess, P., 2006. Tissue distribution and effects of heat treatments on the content of domoic acid in blue mussels, Mytilus edulis. Toxicon 47, 473-479.

McCarron, P., Kilcoyne, J., Hess, P., 2008. Effects of cooking and heat treatment on concentration and tissue distribution of okadaic acid and dinophysistoxin-2 in mussels (Mytilus edulis). Toxicon 51, 1081-1089.

McCarron, P., Rourke, W.A., Hardstaff, W., Pooley, B., Quilliam, M.A., 2012. Identification of pinnatoxins and discovery of their fatty acid ester metabolites in mussels (Mytilus edulis) from Eastern Canada. J. Agric. Food Chem. 60, 1437-1446.

McNabb, P.S., McCoubrey, D.J., Rhodes, L., Smith, K., Selwood, A.I., Munday, R., Holland, P.T., 2012. New perspectives on biotoxin detection in Rangaunu Harbour, New Zealand arising from the discovery of pinnatoxins. Harmful Algae 13, 34-39.

Miles, C.O., Rundberget, T., Sandvik, M., Aasen, J.A.B., Selwood, A.I., 2010. The presence of pinnatoxins in Norwegian mussels. National Veterinary Institute, Report 07b, p. 10 pages.

Munday, R., 2008. Toxicology of cyclic imines: gymnodimine, spirolides, pinnatoxins, pteriatoxins, prorocentrolide, spiro-prorocentrimine and symbioimines. Chapter 27 in: . Seafood and freshwater toxins - Pharmacology, Physiology and Detection; ed. L. Botana. CRC Press, Taylor \& Francis Group, ISBN: 0-8493-7437-5.

Munday, R., Selwood, A.I., Rhodes, L., 2012. Acute toxicity of pinnatoxins E, F and G to mice. Toxicon 60, 995-999.

Nézan, E., Chomérat, N., 2011. Vulcanodinium rugosum gen. et sp. nov. (Dinophyceae), un nouveau dinoflagellé marin de la côte méditerranéenne française. Cryptogamie, Algologie 32, 3-18.

Rhodes, L., Smith, K., Selwood, A., McNabb, P., van Ginkel, R., Holland, P., Munday, R., 2010. Production of pinnatoxins by a peridinoid dinoflagellate isolated from Northland, New Zealand. Harmful Algae 9, 384-389.

Rundberget, T., Aasen, J.A.B., Selwood, A.I., Miles, C.O., 2011. Pinnatoxins and spirolides in Norwegian blue mussels and seawater. Toxicon 58, 700-711.

Selwood, A.I., Miles, C.O., Wilkins, A.L., van Ginkel, R., Munday, R., Rise, F., McNabb, P., 2010. Isolation, structural determination and acute toxicity of pinnatoxins $E, F$ and $G$. J. Agric. Food Chem. 58, 6532-6542.

Sleno, L., Chalmers, M.J., Volmer, D.A., 2004. Structural study of spirolide marine toxins by mass spectrometry - Part II. Mass spectrometric characterization of unknown spirolides and related compounds in a cultured phytoplankton extract. Anal. Bioanal. Chem. 378, 977-986.

Smith, K.F., Rhodes, L.L., Suda, S., Selwood, A.I., 2011. A dinoflagellate producer of pinnatoxin G, isolated from sub-tropical Japanese waters. Harmful Algae 10, 702-705. 
Takada, N., Umemura, N., Suenaga, K., Chou, T., Nagatsu, A., Haino, T., Yamada, K., Uemura, D., 2001a. Pinnatoxins B and C, the most toxic components in the pinnatoxin series from the Okinawan bivalve Pinna muricata. Tetrahedron Lett. 42, 3491-3494.

Takada, N., Umemura, N., Suenaga, K., Uemura, D., 2001b. Structural determination of pteriatoxins $A, B$ and $C$, extremely potent toxins from the bivalve Pteria penguin. Tetrahedron Lett. 42, 3495-3497.

Touzet, N., Franco, J.M., Raine, R., 2008. Morphogenetic diversity and biotoxin composition of Alexandrium (Dinophyceae) in Irish coastal waters. Harmful Algae 7, 782-797.

Uemura, D., Chou, T., Haino, T., Nagatsu, A., Fukuzawa, S., Zheng, S., Chen, H., 1995. Pinnatoxin A: a toxic amphoteric macrocycle from the Okinawan bivalve Pinna muricata. J. Am. Chem. Soc. 117, 1155-1156.

Yanagi, T., Murata, M., Torigoe, K., and Yasumoto, T., 1989. Biological activities of semisynthetic analogs of dinophysistoxin-3, the major diarrhetic shellfish toxin. Agric. Biol. Chem., 53, 525-529.

Yasumoto, T., Murata, M., Oshima, Y., Masumoto, K., Clardy, J., 1984. Diarrhetic shellfish poisoning. In E.P. Ragelis (ed.), Seafood Toxins. Washington D.C., American Chemical Society (ACS Symposium Series 262) pp. 207-214.

Zeng, N., Gu, H., Smith, K.F., Rhodes, L.L., Selwood, A.I., Yang, W., 2012. The first report of Vulcanodinium rugosum (Dinophyceae) from the South China Sea with a focus on the life cycle. N. Z. J. Mar. Freshw. Res. 46, 511-521.

Zheng, S.Z., Huang, F.L., Chen, S.C., Tan, X.F., Zuo, J.B., Peng, J., Xie, R.W., 1990. The isolation and bioactivities of pinnatoxin. Chin. J. Mar. Drugs 33, 33-35. 
Table 1. Pinnatoxin G (PnTX-G) and 13-desmethyl-spirolide-C (13-dmSPX-C) in French vigilance samples (April to July 2010). Oysters are C. gigas while mussels are $M$. edulis North of Arcachon and M. galloprovincialis South of Arcachon, with mussels at Arcachon likely to be a hybrid.

\begin{tabular}{|c|c|c|c|c|}
\hline \multirow{2}{*}{$\begin{array}{c}\text { Sampling } \\
\text { date }\end{array}$} & \multirow{2}{*}{ Sampling site } & \multirow{2}{*}{ Species } & PnTX-G & 13dmSPX-C \\
\hline & & & $\mu \mathrm{g} / \mathrm{kg}$ & $\mu \mathrm{g} / \mathrm{kg}$ \\
\hline $12 / 04 / 2010$ & Banc Arguin sud & Oysters & nd & 8 \\
\hline $12 / 042010$ & Banc Arguin sud & Mussels & nd & 9 \\
\hline $12 / 04 / 2010$ & Le Grand Traict & Mussels & nd & 8 \\
\hline $12 / 04 / 2010$ & Kervoyal & Mussels & nd & 6 \\
\hline $13 / 04 / 2010$ & Antifer & Mussels & nd & nd \\
\hline $14 / 04 / 2010$ & Pointe de St Quentin & Mussels & nd & nd \\
\hline $14 / 04 / 2010$ & Le Scoré & Mussels & nd & 16 \\
\hline $19 / 04 / 2010$ & Ronce & Oysters & nd & 9 \\
\hline $19 / 04 / 2010$ & Diana centre & Mussels & nd & 3 \\
\hline $19 / 04 / 2010$ & Parc Leucate & Mussels & nd & nd \\
\hline $19 / 04 / 2010$ & Parc Leucate & Oysters & nd & nd \\
\hline $19 / 04 / 2010$ & Etang du Prévost & Mussels & 3 & 2 \\
\hline $27 / 04 / 2010$ & Pointe Agon nord & Mussels & nd & nd \\
\hline $05 / 05 / 2010$ & Le Scoré & Mussels & nd & 19 \\
\hline $17 / 05 / 2010$ & Banc Arguin sud & Oysters & nd & 6 \\
\hline $17 / 05 / 2010$ & Banc Arguin sud & Mussels & nd & 7 \\
\hline $17 / 05 / 2010$ & Kervoyal & Mussels & nd & 4 \\
\hline $17 / 05 / 2010$ & Le Grand Traict & Mussels & nd & 6 \\
\hline $17 / 05 / 2010$ & Ronce & Oysters & nd & 18 \\
\hline $17 / 05 / 2010$ & Diana centre & Mussels & nd & 2 \\
\hline $19 / 05 / 2010$ & Pointe de St Quentin & Mussels & nd & nd \\
\hline $25 / 05 / 2010$ & Parc Leucate & Mussels & nd & nd \\
\hline $25 / 05 / 2010$ & Parc Leucate & Oysters & nd & nd \\
\hline $25 / 05 / 2010$ & Antifer & Mussels & nd & nd \\
\hline $27 / 05 / 2010$ & Pointe Agon nord & Mussels & nd & nd \\
\hline $02 / 06 / 2010$ & Le Scoré & Mussels & nd & 13 \\
\hline $14 / 06 / 2010$ & Banc Arguin sud & Mussels & nd & 3 \\
\hline $13 / 06 / 2010$ & Le Grand Traict & Mussels & nd & 6 \\
\hline $14 / 06 / 2010$ & Diana centre & Mussels & nd & 1 \\
\hline $14 / 06 / 2010$ & Antifer & Mussels & nd & 1 \\
\hline $15 / 06 / 2010$ & Pointe Agon nord & Mussels & nd & nd \\
\hline $15 / 06 / 2010$ & Ronce & Oysters & nd & 5 \\
\hline $14 / 06 / 2010$ & Kervoyal & Mussels & nd & 4 \\
\hline $14 / 06 / 2010$ & Parc Leucate & Oysters & nd & nd \\
\hline $01 / 07 / 2010$ & Le Scoré & Mussels & 3 & 10 \\
\hline $12 / 07 / 2010$ & Le Grand Traict & Mussels & nd & 5 \\
\hline $05 / 07 / 2010$ & Antifer & Mussels & nd & 1 \\
\hline $19 / 07 / 2010$ & Etang du Prévost & Mussels & 7 & 14 \\
\hline $19 / 07 / 2010$ & Diana centre & Mussels & nd & 1 \\
\hline $19 / 07 / 2010$ & Parc Leucate & Oysters & nd & nd \\
\hline $19 / 07 / 2010$ & Kervoyal & Mussels & nd & 3 \\
\hline $19 / 07 / 2010$ & Banc Arguin sud & Mussels & nd & 5 \\
\hline
\end{tabular}

n.d. not detected (LOD at Norwegian Veterinary Institute for PnTX-G and 13-dmSPX-C is $0.5 \mu \mathrm{kg}^{-1}$ ) 
Table 2. Comparison of the contamination of mussels (M. galloprovincialis) with that in clams (V. decussata). WF = whole flesh

\begin{tabular}{|c|c|c|c|}
\hline \multirow{2}{*}{$\begin{array}{l}\text { Sampling } \\
\text { date }\end{array}$} & Clams & Mussels & \multirow{2}{*}{$\begin{array}{c}\text { Ratio } \\
\text { mussels/ } \\
\text { clams }\end{array}$} \\
\hline & \multicolumn{2}{|c|}{ PnTX-G ( $\left.\mu \mathrm{g} \mathrm{kg}^{-1} \mathrm{WF}\right)$} & \\
\hline $11 / 05 / 2010$ & 28 & 89 & 3 \\
\hline 29/06/2010 & 24 & 102 & 4 \\
\hline $12 / 07 / 2010$ & 24 & 137 & 6 \\
\hline $28 / 07 / 2010$ & 27 & 121 & 4 \\
\hline 09/08/2010 & 22 & 95 & 4 \\
\hline $31 / 08 / 2010$ & 19 & 282 & 15 \\
\hline $27 / 09 / 2010$ & 19 & 297 & 16 \\
\hline $24 / 10 / 2010$ & 18 & 125 & 7 \\
\hline $18 / 07 / 2011$ & 23 & 121 & 5 \\
\hline $01 / 08 / 2011$ & 55 & 459 & 8 \\
\hline $31 / 08 / 2011$ & 95 & 324 & 3 \\
\hline $27 / 09 / 2011$ & 28 & 421 & 15 \\
\hline $23 / 11 / 2011$ & 19 & 37 & 2 \\
\hline $29 / 11 / 2011$ & 21 & 202 & 10 \\
\hline $13 / 12 / 2011$ & 17 & 181 & 11 \\
\hline & & average & 7,6 \\
\hline & & CV (\%) & 60,4 \\
\hline
\end{tabular}

Table 3. Percentage of pinnatoxin A (PnTX-A) versus G (PnTX-G) in clams (V. decussata) and mussels $(M$. galloprovincialis). $\mathrm{n} / \mathrm{a}=$ not applicable due to PnTX-A not being quantifiable or below the limit of detection.

\begin{tabular}{|c|c|c|}
\hline Sampling date & Clams & Mussels \\
\hline & \multicolumn{2}{|c|}{ Ratio PnTX-A/PnTX-G (\%) } \\
\hline $18 / 07 / 2011$ & 2.1 & 0.9 \\
\hline $01 / 08 / 2011$ & 2.2 & 0.8 \\
\hline $31 / 08 / 2011$ & 1.2 & 0.6 \\
\hline $27 / 09 / 2011$ & 2.0 & 0.5 \\
\hline 23/11/2011 & $\mathrm{n} / \mathrm{a}$ & 3.7 \\
\hline 29/11/2011 & $\mathrm{n} / \mathrm{a}$ & 0.8 \\
\hline $13 / 12 / 2011$ & $\mathrm{n} / \mathrm{a}$ & 0.6 \\
\hline $13 / 03 / 2012$ & $\mathrm{n} / \mathrm{a}$ & $\mathrm{n} / \mathrm{a}$ \\
\hline 28/03/2012 & $\mathrm{n} / \mathrm{a}$ & $\mathrm{n} / \mathrm{a}$ \\
\hline average & 1.9 & 1.1 \\
\hline $\mathrm{CV}(\%)$ & 25 & 100 \\
\hline
\end{tabular}


Table 4. Tissue distribution of PnTX-G in mussels ( $M$. galloprovincialis) from Ingril lagoon. Analyses of whole flesh (WF) are compared to analysis of digestive glands (DG). All concentrations are expressed as whole flesh equivalents, i.e. analyses of digestive glands have been weighted by the percentage of the digestive gland of the whole flesh. Nota bene: only ca. $65 \%$ of the total PnTX-G accumulated in the digestive gland on average.

\begin{tabular}{|c|c|c|c|}
\hline $\begin{array}{c}\text { Sampling } \\
\text { date }\end{array}$ & $\begin{array}{c}\text { PnTX-G } \\
{\left[\mu \mathrm{kg}^{-1}\right]}\end{array}$ & $\begin{array}{c}\text { PnTX-G } G_{D G} \\
{\left[\mu \mathrm{g} \mathrm{kg}{ }^{-1}\right]}\end{array}$ & $\begin{array}{c}\text { PnTX-G }{ }_{D G} / \\
\text { PnTX-GWF } \\
{[\%]}\end{array}$ \\
\hline $10 / 01 / 2012$ & 154 & 117 & 76 \\
\hline $23 / 01 / 2012$ & 52 & 17 & 34 \\
\hline $06 / 02 / 2012$ & 197 & 106 & 54 \\
\hline 20/02/2012 & 121 & 68 & 56 \\
\hline $13 / 03 / 2012$ & 43 & 22 & 51 \\
\hline $28 / 03 / 2012$ & 145 & 61 & 42 \\
\hline $11 / 04 / 2012$ & 454 & 31 & 7 \\
\hline $14 / 05 / 2012$ & 134 & 54 & 40 \\
\hline $25 / 06 / 2012$ & 430 & 265 & 62 \\
\hline $02 / 07 / 2012$ & 481 & 227 & 47 \\
\hline $06 / 08 / 2012$ & 652 & 494 & 76 \\
\hline $10 / 09 / 2012$ & 205 & 36 & 18 \\
\hline 08/10/2012 & 25 & 46 & 180 \\
\hline \multirow[t]{2}{*}{$06 / 11 / 2012$} & 11 & 19 & 173 \\
\hline & & Average & 65,4 \\
\hline
\end{tabular}




\section{Figures}

Figure 1. Structures of pinnatoxin A (PnTX-A) and G (PnTX-G), spirolide $B$ and 13-desmethyl spirolide D (13-dmSPX-D). PnTX-G, SPX-B and 13-dmSPX-D all have the same sum formula and consequently the same accurate mass, even though pinnatoxins are produced by $V$. rugosum and spirolides are produced by $A$. ostenfeldii. PnTXs and SPXs possess several molecular features in common: a cyclic imine, a tri-spiro ring assembly and a macrocycle but PnTX-G differs from SPXs through the heptacyclic ether with an additional ether-bridge.

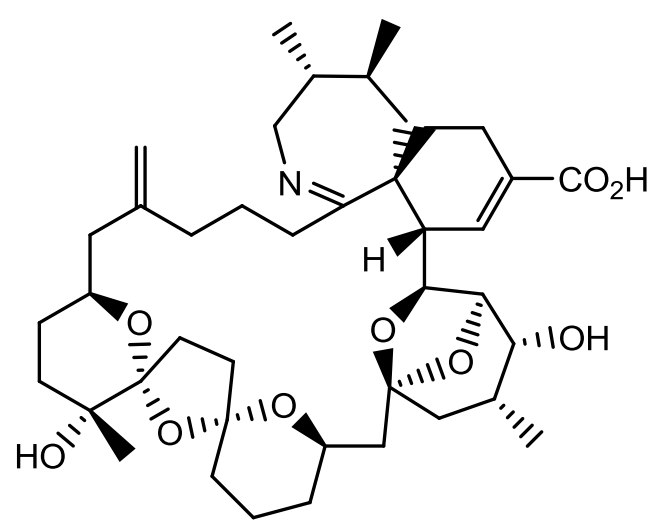

PnTX-A

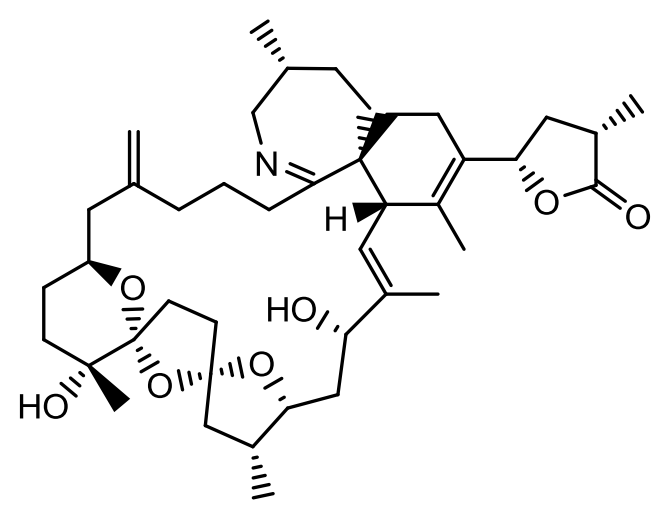

SPX-B

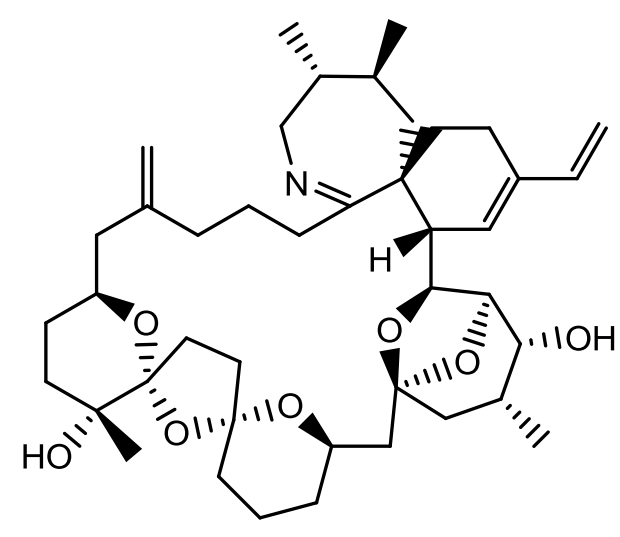

PnTX-G

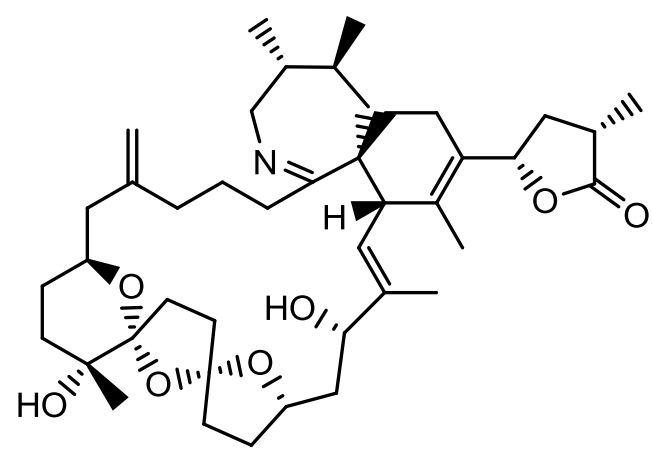

13-dm SPX-D 
Figure 2. Map of French coastline with the sites selected for vigilance surveillance and Ingril Lagoon. Vigilance surveillance is complementary to routine surveillance and uses the lipophilic mouse bioassay as a screen for novel or emerging toxins. Sites have been selected for geographical spread, to reflect important shellfish production areas and from historical knowledge of bioassay results. The sampling site " tang du Prévost" (Table 1) is connected to " ngril Lagoon" and situated to the east of it.

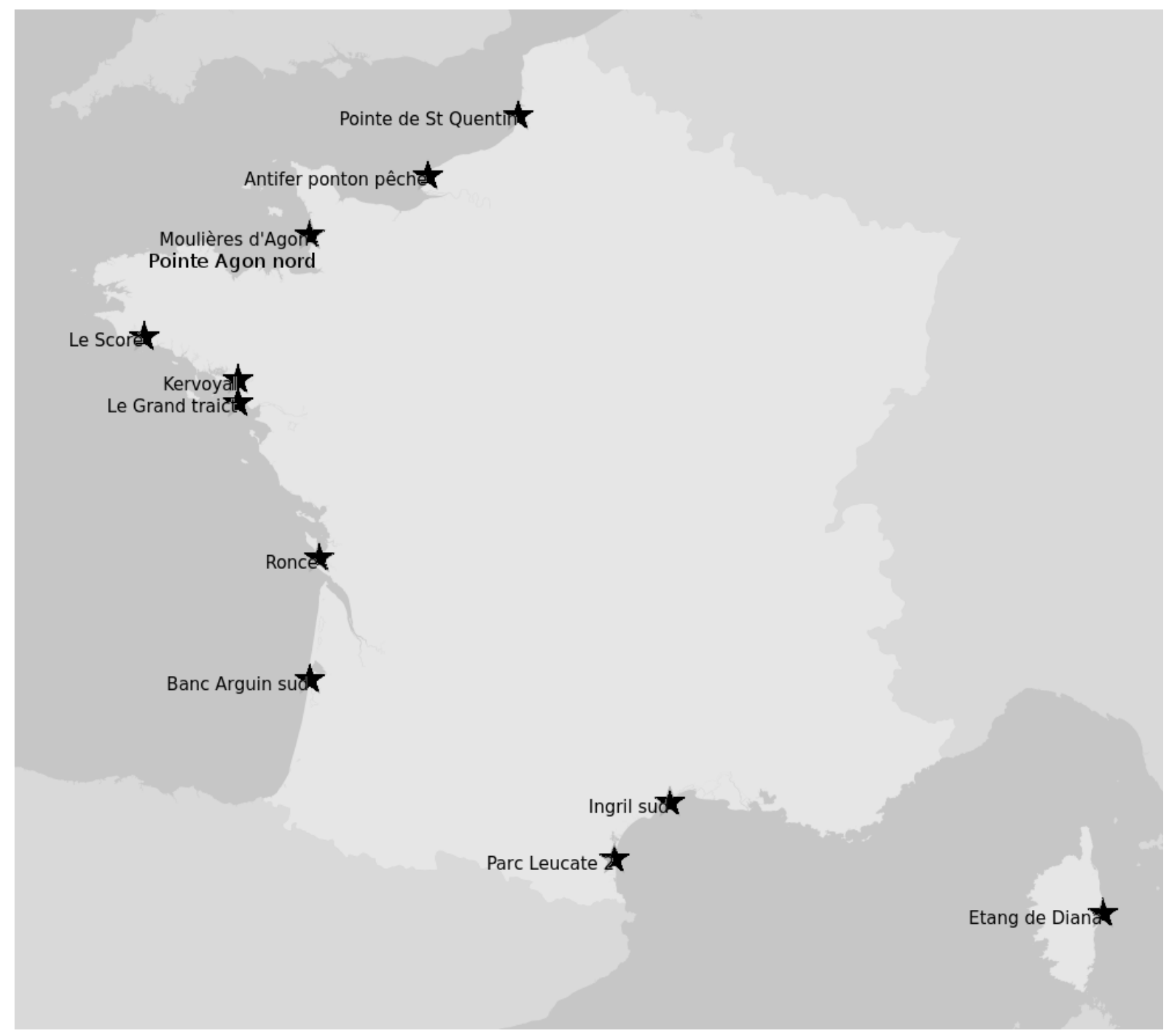


Figure 3. Chromatograms (left) and high-resolution mass spectrometry spectra (right) of PnTX-G in a culture of Vulcanodinium rugosum isolated from Ingril (top) and in the standard from New Zealand characterised at NRCC (bottom). Spectra were acquired on the Agilent 6540 Q-ToF instrument. Note presence of 458 fragment ion, specific for PnTX-G compared to SPX-B and 13-desmethyl-SPX-D. The spectrum shown is the sum of the three spectra at 20, 40 and $60 \mathrm{eV}$. For fragmentation pathway also see Figure 3 of the electronic supplementary material.
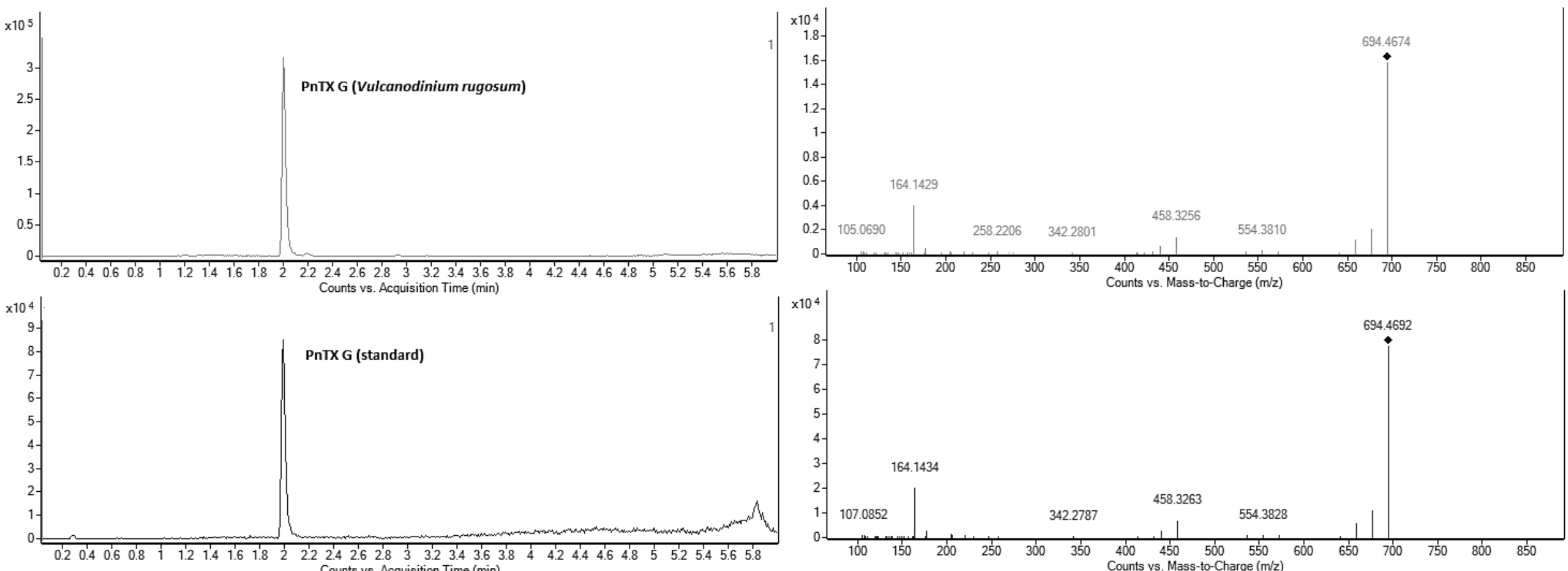
Figure 4. Comparison of natural PnTX-G with PnTX-G from chemical synthesis by using the Torpedo microplate binding assay. Inhibition of specific biotin- $\alpha-B u n g a r o t o x i n$ binding to Torpedo-nAChR by increasing concentrations of natural (blue circles) and synthetic (red circles) PnTX-G. Curve fitting was performed by nonlinear regression analysis using the Hill equation. Each data point is the mean value \pm standard error of the mean of 3 paired determinations. The dashed lines represent the $95 \%$ confidence band of the inhibition curve. The calculated $\mathrm{IC}_{50}$ for natural PnTX-G was $0.139 \mathrm{nM}(0.113-172 \mathrm{nM}, 95 \%$ confidence intervals), and for synthetic PnTX-G $0.236 \mathrm{nM}(0.159-0.352 \mathrm{nM}, 95 \%$ confidence intervals).

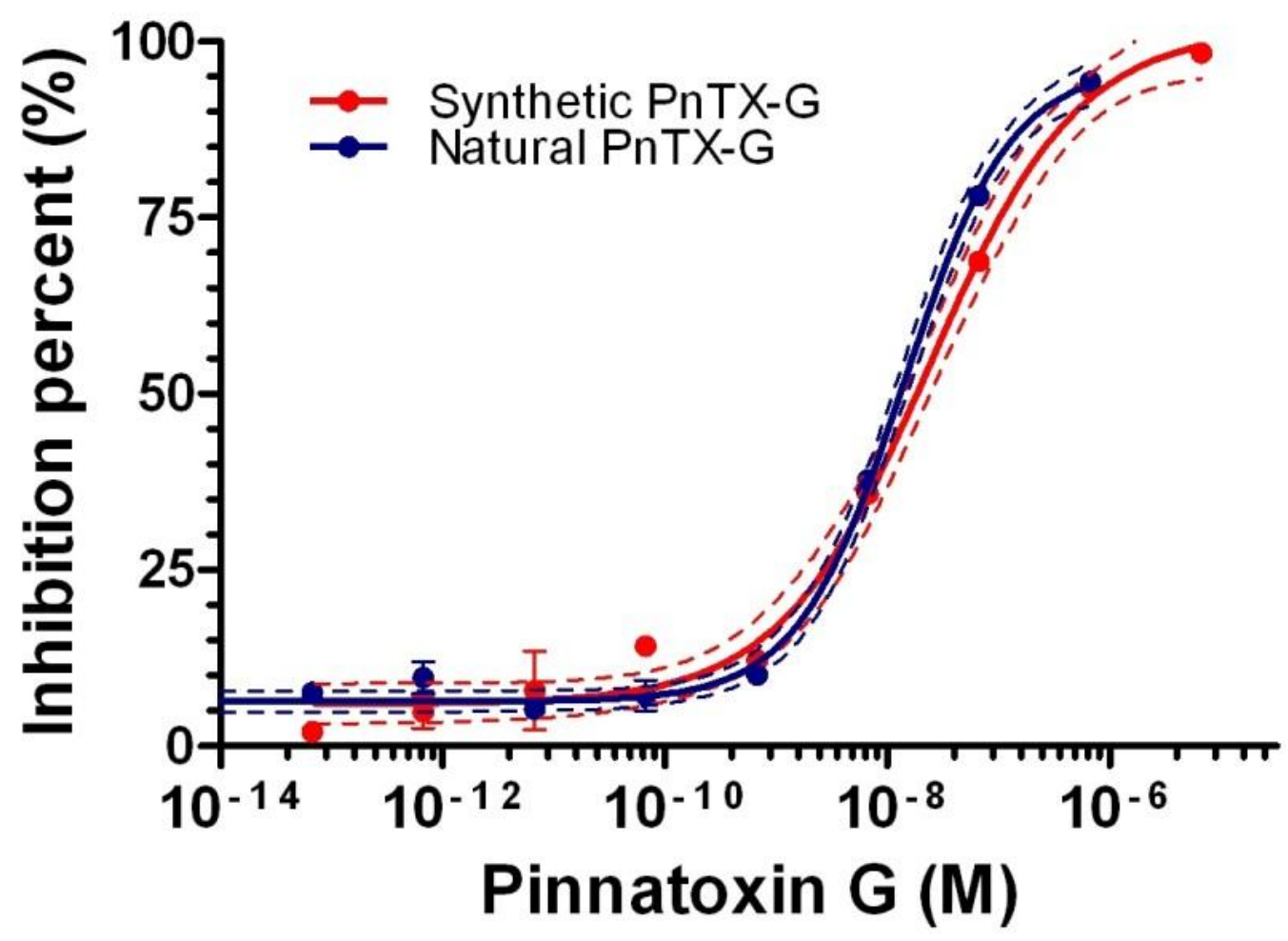


Figure 5. Annual variations of Pinnatoxin $G(P n T X-G)$ in mussels and clams from Ingril Lagoon (French Mediterranean Sea) in comparison to the mouse bioassay detection limit (MBA-LOD) of $40 \mu \mathrm{g} \mathrm{kg}^{-1}$. All data are expressed in whole flesh equivalents; nota bene: clam concentrations have been multiplied by ten for illustration purposes only and mussels in 2009 had been analysed as digestive glands and whole flesh values were recalculated from the weight ratios of digestive glands and remainder. Mussels and clams from 2010 to 2012 had been analysed as whole flesh samples. No monitoring was carried out during the periods where no data points are visible on the four graphs. For comparative purposes, the mouse bioassay detection limit (MBA-LOD) of $40 \mathrm{\mu g} \mathrm{kg}^{-1}$ is indicated with a horizontal line
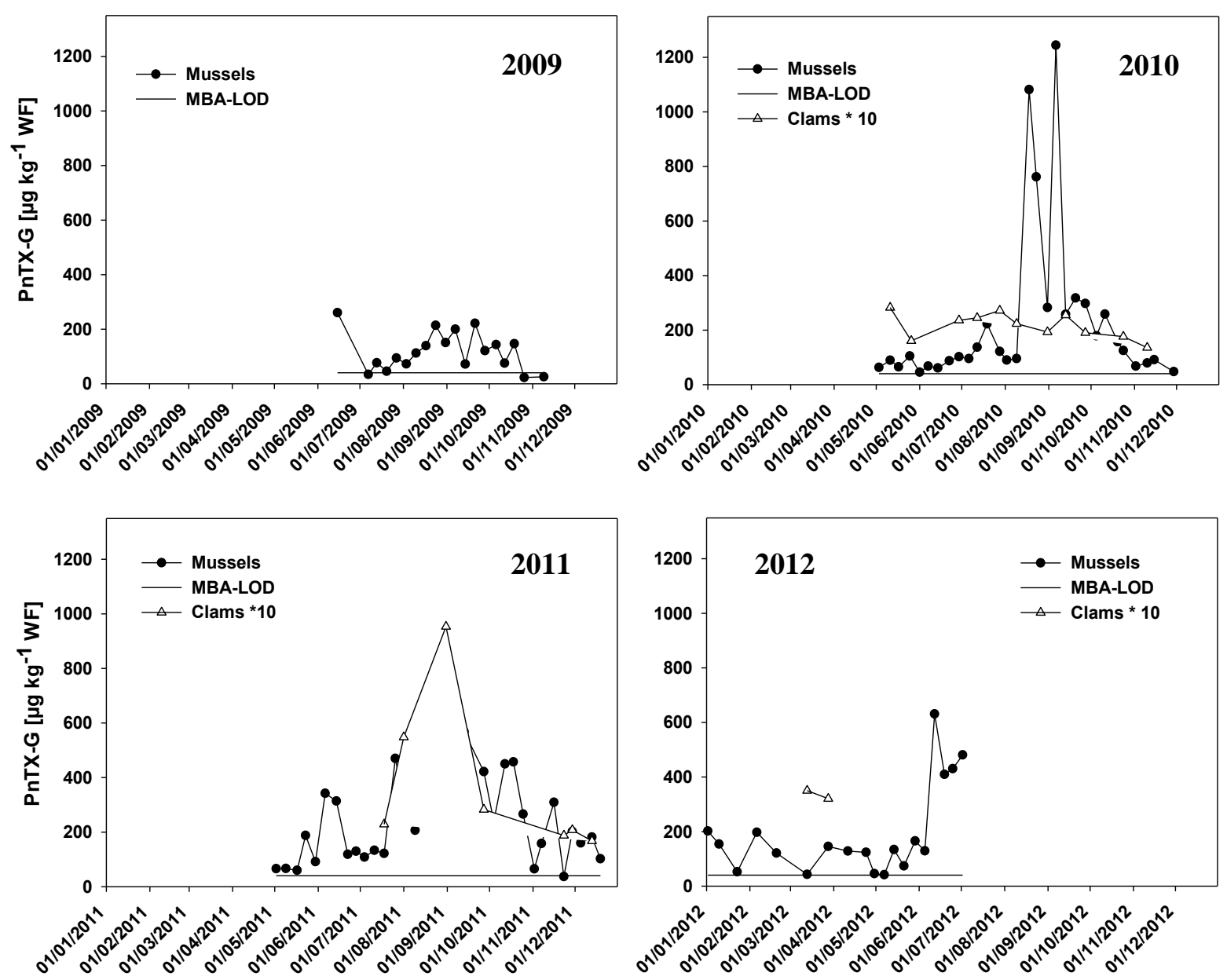